\title{
Screening of Helicobacter Pylori in Patients with Dyspeptic Complaints with the Urea Breath Test and Its Usability in Family Medicine
}

\author{
Üre Nefes Testi ile Helicobacter Pylori’nin Dispeptik Şikâyetleri Olan \\ Hastalarda Taranması ve Aile Hekimliğinde Kullanılabilirliği
}

Mustafa Bayraktar ${ }^{1}$, Mustafa Reşat Dabak ${ }^{2}$

\begin{abstract}
Objective: Helicobacter pylori (H.pylori) is a common cause of gastritis, peptic ulcer disease, gastric lymphoma, and gastric cancer. H.pylori positive in patients with dyspeptic complaints should be investigated in order to determine the etiology and reduce the risk of H.pylori-related malignancy. The urea breath test (UBT) is a simple, convenient, and highly accurate H.pylori screening test with excellent sensitivity and specificity. The utility of UBT as a screening test in family medicine was examined in this study, that investigated at H.pylori positive in patients with dyspeptic complaints. Method: A retrospective, cross-sectional, descriptive, single-center study was conducted. The results of the C14-UBT for H.pylori were investigated by scanning the archives of patients over the age of 18 who applied with dyspeptic complaints in an education and research hospital within a calendar year. In the evaluation of UBT results, $\geq 50 \mathrm{cpm}$ was considered positive, $<25 \mathrm{cpm}$ negative, and $25-50 \mathrm{cpm}$ was considered suspicious. Results: The UBT findings of 1192 patients were included, with an acceptability rate of 83 percent. The average age of the participants was $48.7 \pm 15.3$ years, with 61 percent of them being women and 39 percent being men. The UBT was $81.5 \mathrm{cpm}$ on average $(\mathrm{IQR}=214$, $\min =0$, max $=909)$. According to the findings, 56 percent ( $\mathrm{n}=667)$ of the participants tested positive for H.pylori, 43.2 percent $(n=515)$ tested negative for H.pylori, and 0.8 percent $(n=10)$ tested suspicious for H.pylori. Although 56.4 percent of women and 55.3 percent of males tested positive for H.pylori, there was no statistically significant difference (p>0.05). Conclusion: In this study conducted on a large group of patients, H.pylori positivity was found in $56 \%$ with the UBT. Considering this result, it has been evaluated that, in cases where the World Health Organization recommends H.pylori screening, and in patients with dyspeptic complaints but no alarm symptoms, H.pylori should be screened with urea breath test in Family Health Centers as an important preventive healthcare service.
\end{abstract}

Keywords: Urea breath test, Helicobacter pylori, dyspepsia, screening, family medicine

\section{ÖZET}

Amaç: Helicobacter pylori (H.pylori), gastrit, peptik ülser, gastrik lenfoma ve gastrik karsinomunun en önemli nedenlerinden biridir. Dispeptik şikâyetleri olan hastalarda H.pylori pozitifliğinin araştırılması, hem hasta şikâyetlerinin giderilmesi, hem de H.pylori'ye bağlı kanser gelişim riskinin önlenmesi açısından önemlidir. H.pylori tarama testlerinden üre nefes testi, kolay, pratik ve yüksek sensitivite ve spesifisite düzeyi ile oldukça güvenilir bir testtir. Bu çalışmada, dispeptik şikâyetleri olan hastalarda üre nefes testi ile H.pylori pozitifliği araştırılmış, üre nefes testinin Aile Hekimliğinde tarama amaçlı kullanılabilirliği incelenmiştir. Yöntem: Bu çalışma retrospektif, kesitsel, tanımlayıcı, tek merkezli bir çalışmadır. Üçüncü basamak eğitim araştırma hastanesinde arşiv taraması yapılarak, bir takvim yılı içerisinde dispeptik şikâyetler ile başvuran 18 yaş üstü hastaların, H.pylori için yapılan C14 üre nefes test sonuçları incelenmiştir. Üre nefes test sonucu değerlendirmesinde, $50 \mathrm{cpm}$ ve üzeri pozitif, $<25 \mathrm{cpm}$ ise negatif, 25 ile $50 \mathrm{cpm}$ arası şüpheli olarak alınmıştır. Bulgular: Çalışmamıza toplam 1192 hastanın üre nefes test sonucu dâhil edilmiş, çalışmaya alınan hastaların oranı \% 83 olmuştur. Hastaların \%61'i kadın, \%39'u erkek idi. Yaş ortalaması 48,7 15,3 yıl olarak bulunmuştur. Üre nefes test sonuçlarına göre hastaların \%56'sı (n=667) H.pylori pozitif, \%43,2'si (n=515) H.pylori negatif, \%0,8'inin ( $\mathrm{n}=10)$ ise şüpheli test sonucu olduğu saptanmıştır. Üre nefes test sonucu ortancası $81.5 \mathrm{cpm}$ (IQR=214, Min=0, Max=909) olarak tespit edilmiştir. Kadınlarda H.pylori pozitifliği \%56,4; erkeklerde \%55,3 olarak saptanmış, ancak istatistiksel olarak cinsiyete göre H.pylori pozitifliğinde anlamlı farklılık saptanmamıştır ( $>0,05)$. Sonuç: Geniş bir hasta grubu üzerinde yapılan bu çalışmamızda, üre nefes testi ile \%56 oranında H.pylori pozitifliği saptanmıştır. Bu sonuç dikkate alındığında, Dünya Sağlık Örgütü’nün H.pylori taramasını önerdiği durumlarda ve dispeptik şikâyetleri olan ancak alarm semptomları olmayan hastalarda, önemli bir koruyucu sağlık hizmeti olarak üre nefes testi ile H.pylori taramasının Aile Sağlığı Merkezlerinde yapılmasının uygun olabileceği değerlendirilmiștir.

Anahtar Kelimeler: Üre nefes testi, Helicobacter pylori, dispepsi, tarama, aile hekimliği

Received / Geliș tarihi: 21.01.2021, Accepted / Kabul tarihi: 13.09.2021

${ }^{1}$ Atatürk Üniversitesi Tıp Fakültesi Aile Hekimliği Anabilim Dalı

2 İstanbul Haseki Eğitim ve Araştırma Hastanesi Aile Hekimliği Anabilim Dalı

*Address for Correspondence / Yazışma Adresi: Mustafa Bayraktar, Atatürk Üniversitesi Tıp Fakültesi Aile Hekimliği Anabilim Dalı Erzurum/ Türkiye,

E-mail: mustafabayraktar@atauni.edu.tr

Bayraktar M, Dabak R. Screening of Helicobacter Pylori in Patients with Dyspeptic Complaints with the Urea Breath Test and Its Usability in Family Medicine. TJFMPC, 2021;15(4): 763-768.

DOI $10.21763 / \mathrm{tjfmpc} .865772$

Bayraktar and Dabak., TJFMPC www.tjfmpc.gen.tr 2021; 15 (4) 


\section{INTRODUCTION}

According to data from the Health Statistics Yearbook, digestive system and metabolic group pharmaceuticals were the most prescribed and spent drugs in Turkey in 2018, accounting for 5.2 billion liras and 400 million boxes. ${ }^{1}$ Similarly, the daily drug usage per thousand persons in the digestive system category in Turkey was nearly double the OECD average, according to the data presented. These notable statistics demonstrate that it is unavoidable to explore the causes of the high number of boxes and prescribing percentages of digestive system medications, as well as to propose strategies to lower these rates.

Proton pump inhibitors (PPI), H2 receptor blockers, and antacids are the first pharmaceuticals that come to mind when it comes to digestive system pills. They are generally administered for dyspeptic problems. Dyspeptic complaints can be caused by a variety of disorders, ranging from benign conditions like gastroesophageal reflux, gastritis, and gastric and duodenal ulcers to more serious conditions like esophageal or gastric adenocarcinoma or severe malignant diseases. ${ }^{2}$ Among these complaints, it is known that, one of the most important cause of chronic gastritis, peptic ulcer, gastric lymphoma and carcinoma is Helicobacter pylori (H. pylori), a gram-negative microaerophilic bacterium colonizing in the stomach. ${ }^{3} \mathrm{H}$. pylori infections can be effectively treated with antibiotic therapy and can be eradicated in patients in just 10-14 days with short-term treatments. ${ }^{4}$ With the early detection and eradication treatment of the $\mathrm{H}$. pylori, there will be a chance to cure and prevent the severe and malignant course of $\mathrm{H}$. pylori infections. Therefore, H. pylori should be screened and treated in people with dyspeptic complaints to prevent adverse outcomes such as gastric cancer due to $H$. pylori infections, and to reduce the cost of the unnecessary widespread medication use. ${ }^{5}$

One of the non-invasive tests used in the diagnosis and screening of $\mathrm{H}$. pylori is the urea breath test. The urea breath test is recommended as the preferred test for mass screening of $\mathrm{H}$. pylori in the population. ${ }^{6}$ For the test, the urea tablet containing labeled carbon $(\mathrm{C} 13$ or $\mathrm{C} 14)$ is given to the patient, carbon dioxide is released in the presence of $\mathrm{H}$. pylori in the stomach and this labeled carbon is detected in the patients' breath. ${ }^{7}$ The urea breath test is a non-invasive, easy, and safe test that gives results as fast as in an hour and has a very low negligible radiation exposure rates. ${ }^{8,9}$ On the other hand, it has approximately 90 percent sensitivity and specificity levels. ${ }^{10,11}$ Since it is an easy, reliable and harmless test, the urea breath test can be offered to be performed at the Family Health Centers (FHCs). However, in order for this screening test to be performed in patients with dyspeptic complaints, the local prevalence of $\mathrm{H}$. pylori should be more than $10 \%{ }^{12}$

The goal of this study was to acquire data on the prevalence of $\mathrm{H}$. pylori in the population by analyzing $\mathrm{H}$. pylori positivity with the urea breath test in patients with dyspeptic complaints in order to explore the applicability of the urea breath test in FHCs.

\section{METHODS}

This study was conducted as a retrospective, cross-sectional, descriptive study in a singlecenter, in a tertiary education and research hospital. Local ethics committee approval was obtained prior to the study (ethics committee approval date and number: 13.03.12/8). Informed consent could not be obtained from the patients because the study was planned as a retrospective file scan. The demographic properties (age and gender) and urea breath test results of patients were noted.

Within the scope of our study, the hospital archives were scanned and the urea breath test results for $\mathrm{H}$. pylori of patients over the age of 18, who presented with dyspeptic complaints within a calendar year were retrospectively analyzed. Patients under the age of 18 , with incomplete information or missing test results, and retest results of the same person in a short time period were excluded from the study. The C14 urea breath test was performed according to the usual instructions and procedures. The reference values of our hospital $(>50 \mathrm{cpm}=$ positive, $<25 \mathrm{cpm}=$ negative, $25-50 \mathrm{cpm}=$ suspicious) were taken into consideration in the evaluation of the urea breath test results.

While investigating the $\mathrm{H}$. pylori test results, it was found that the same patient had more than one test results. Particularly when the first result was positive and the next result was negative, in this case, it was evaluated that these patients received eradication treatment due to $H$. pylori positivity, the second test was the test performed to investigate the treatment efficiency, therefore the first test result was included in the study, and the following results were excluded.

\section{Statistical Analysis}

The demographic characteristics and urea breath test results of the patients were statistically investigated with the SPSS 23.0 (IBM, NY, USA) 
program. Categorical data were presented as frequencies and percentages. The KolmogorovSmirnov test was used to determine the normal distribution of the data. Numerical data were given with mean and standard deviation, if the data were distributed normally; while the median, interquartile range (IQR), minimum (Min) and maximum (Max) values were presented when there is no normal distribution. In the comparison of two independent groups, Mann-Whitney U test was performed when normal distribution was not detected. For the analyses of the categorical data, Pearson's chi-squared test was applied. P $<0.05$ was taken for statistical significance in the study.

\section{RESULTS}

In our study, the total number of patients over the age of 18 who underwent urea breath test in a calendar year, was determined as 1436, by investigating the hospital records. From these results, patients with missing information or test results and repetitive results were excluded in accordance with the exclusion criteria, and as a result, the urea breath test results of a total of 1192 patients were included. Thus, the percentage of patients enrolled in the study was $83 \%$.

When the comprised patients examined, $61 \%(n=727)$ of the patients were female and $39 \%(n=465)$ were male. The mean age of women, men, and all patients was $50.9 \pm 15.9,46$ \pm 14.8 , and $48.7 \pm 15.3$ years, respectively.

The median urea breath test score was $81.5 \mathrm{cpm}(\mathrm{IQR}=214$, Min=0, Max=909). While the median test result of women was $94 \mathrm{cpm}$ $(\mathrm{IQR}=235, \min =0, \max =909)$, the results of men were lower $($ median $=63 \mathrm{cpm} \mathrm{IQR}=185, \mathrm{~min}=0$, $\max =908$ ). The urea breath test results by gender were found to be statistically different $(p=0.025)$.

When urea breath test results were categorized as H.pylori positive (if the test result is greater than $50 \mathrm{cpm}$ ), negative (if the test result is less than $25 \mathrm{cpm}$ ), and suspicious (if the test result is between 25 and $50 \mathrm{cpm}), 56 \%(\mathrm{n}=667)$ of the patients were $\mathrm{H}$. pylori positive, $43.2 \%(\mathrm{n}=$ 515) were $H$. pylori negative, and 10 patients $(0.8 \%)$ were found to have suspicious test results (Figure 1).

Although the urea breath test results were different according to gender, H.pylori positivity was found $56.4 \%$ in women and $55.3 \%$ in men, and this H.pylori positivity was not statistically significant according to gender $(p=0.929)$ (Figure 2). Likewise, when H.pylori positivity was compared according to age, no statistically significant difference was found $(\mathrm{p}=0.546)$.

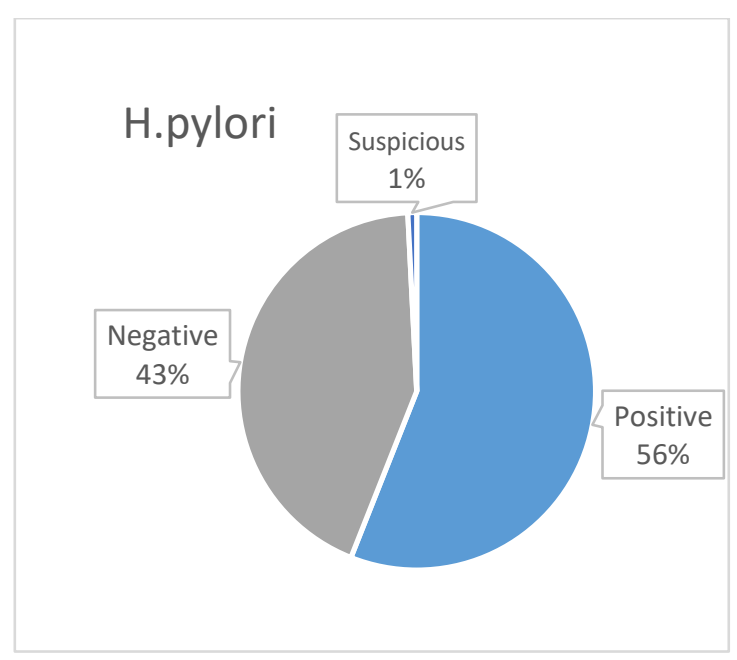

Figure 1. H. pylori positivity in dyspeptic patients with urea breath test

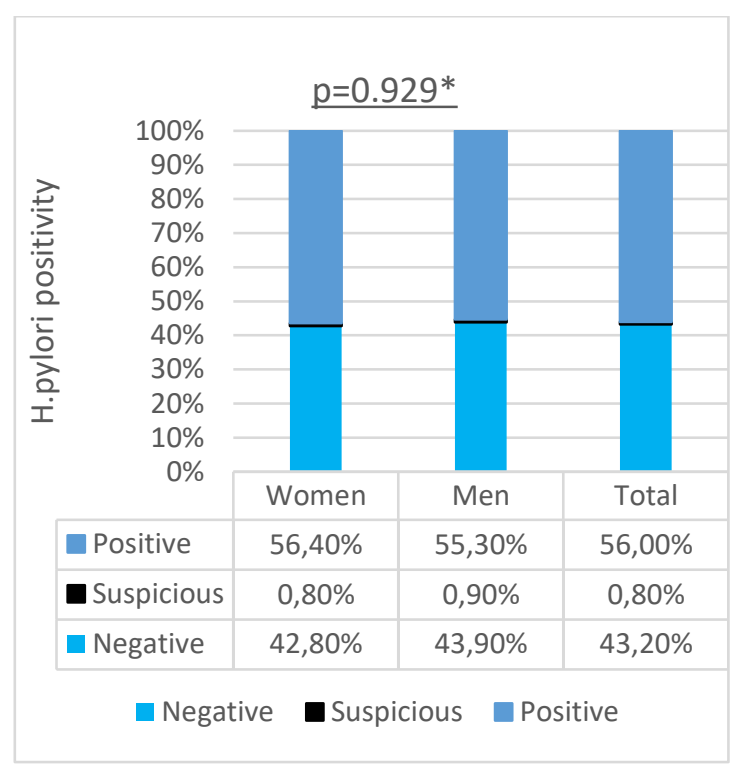

Figure 2. Comparison of urea breath test results in terms of gender

* Pearson's chi-squared test

\section{DISCUSSION}

In this study, according to the results obtained from a non-invasive $\mathrm{C} 14$ urea breath test performed in a large patient group, H. pylori positivity was found to be $56 \%$ in patients with dyspeptic complaints. Studies in the literature have different values regarding $H$. pylori positivity in Turkey. In a recent study, H. pylori positivity in gastric biopsy cultures was found to be $38 \%(n=82)$ in 214 patients with dyspeptic complaints. ${ }^{13}$ In another study conducted on 195 patients complaining of abdominal pain, $\mathrm{H}$. pylori positivity was found to be $44.6 \%$ by gastric biopsy. ${ }^{14}$ In another study conducted on 150 children with dyspeptic complaints, H. pylori 
positivity was found as $33.3 \%$ with the $\mathrm{C} 13$ urea breath test. ${ }^{15}$ All these results were found to be lower than the results of our study, but they were conducted with a lower number of participants compared to our study.

In a previous study investigating ten-year H. pylori positivity changes in Turkey, the frequency of $\mathrm{H}$. pylori was investigated by the invasive urease test method in 550 patients taken between 1994 and 2004, and it was found that the positivity was decreased from $74.2 \%$ to $65.2 \%{ }^{16}$ Although H. pylori positivity was not examined with the same method in our study, the result obtained in that study was similar to our result.

In another study in 2013, the TURHEP study was conducted with the $\mathrm{C} 13$ urea breath test with the wide participation of 4663 people, and $H$. pylori positivity was found to be $82.5 \% .{ }^{17}$ As a remarkable study, this study found that the overall prevalence of $\mathrm{H}$. pylori positivity in the population was quite high. This result reveals that, in patients with certain gastrointestinal disorders or symptoms, H. pylori should first be evaluated as a causative agent. However, the TURHEP study did not question whether the participants had any symptoms, dyspepsia, or gastrointestinal disturbances, and they only presented prevalence of $\mathrm{H}$. pylori in the population. Since most $\mathrm{H}$. pylori positive individuals are known to be asymptomatic, ${ }^{3}$ it is more important to know the frequency of $\mathrm{H}$. pylori positivity in symptomatic individuals or patients with dyspepsia. In our study, we investigated the prevalence of $\mathrm{H}$. pylori in a large group of patients with dyspepsia and the positivity of $\mathrm{H}$. pylori was found to be $56 \%$, and therefore, we think that our study will make a valuable contribution to the literature.

On the other hand, this high H. pylori positivity we obtained reveals and proves the necessity of screening and eradicating $H$. pylori in patients with dyspeptic complaints. Dyspepsia is referred to as symptoms of the gastrointestinal tract, such as epigastric pain or burning, postprandial fullness or early satiety. The prevalence of dyspepsia in the general population is about $20 \%{ }^{18}$ Approximately $80 \%$ of individuals with dyspepsia have no structural explanation for their symptoms and are referred to as functional dyspepsia, and eradication therapy should be offered to the patients with functional dyspepsia who tested positive for H. pylori. ${ }^{19}$

Family Health Centers (FHCs) are important healthcare institutions that provide primary health care services and constitute the first contact point of individuals with healthcare. Within the scope of the duties and responsibilities included in the Family Medicine Law, Family Physicians are required to provide preventive health services to their registered population and screening for early diagnosis and treatment of diseases. In this context, cervical cancer, breast cancer and colorectal cancer screenings are performed by Family Physicians in FHCs. ${ }^{20}$

Among the cancer screenings performed in FHCs, cervical cancer screening should be compared with $H$. pylori screening. While the incidence of cervical cancer in the world in 2016 was reported as 4.3 per 100,000 people, the incidence of gastric cancer was found to be 6.6 per 100,000 people, and therefore gastric cancer is much more common than cervical cancer. ${ }^{1}$ Accordingly, for the prevention or early diagnosis of gastric cancer in patients with dyspeptic complaints, $H$. pylori screening seems reasonable and should be recommended under FHC conditions. For this purpose, the urea breath test, which is an easy, non-invasive, highly specific and sensitive test, should be included and applied in routine screening tests offered in FHCs.

Population-based screening of H. pylori has been discussed in the literature. Many authors and researchers say that $H$. pylori should be screened as gastric cancer is the third most common cancer in the world. Venerito et al, recommended $\mathrm{H}$. pylori screen-and-treat strategy as a part of the primary prevention of the gastric cancer. $^{21}$ In Japan, gastric cancer screening is performed using community-based $\mathrm{H}$. pylori serological tests and Kowada was investigated the cost-effectiveness of $\mathrm{H}$. pylori screening and treatment, and found that, $H$. pylori screening yielded greater benefits at the lower cost than no screening. ${ }^{22}$

Considering the guidelines for dyspeptic complaints, it is recommended to test for $\mathrm{H}$. pylori in dyspeptic patients if the local prevalence of $\mathrm{H}$. pylori exceeds $10 \%{ }^{12}$ Since the $H$. pylori positivity we obtained in our study is $56 \%$ in dyspeptic patients, it is seen that $H$. pylori positivity is high enough to be screened. Noninvasive $H$. pylori test is recommended for patients under 55 years of age with dyspeptic complaints without alarm symptoms. ${ }^{19}$ The American College of Gastroenterology recommended non-endoscopic testing for $\mathrm{H}$. pylori with a recommendation of high efficacy in patients with uninvestigated dyspepsia, those under 60 years of age, and those without alarm features. ${ }^{23}$ Therefore, with these endorsements, it should be considered that dyspeptic patients under 60 years of age and who do not have alarm symptoms should be screened for $\mathrm{H}$. pylori by urea breath test in FHCs. 


\section{CONCLUSION}

In this study conducted on a large patient group, H. pylori positivity was detected as $56 \%$ with the C14 urea breath test in dyspeptic patients. Within the scope of this result, it can be recommended to screen patients with dyspeptic complaints but no alarm symptoms with urea breath test for $\mathrm{H}$. pylori in Family Health Centers. This situation not only considers the recommendations of the World Health Organization, but also emerges as an important preventive health service in order to prevent unnecessary drug use.

Limitation of the Study: Our results do not show the frequency and prevalence of $\mathrm{H}$. pylori positivity throughout the country, since our study was conducted in a single center and in the patients applied to the hospital voluntarily.

Conflict of interest: None of the authors have commercial interests, financial interests and/or other relationships with the manufacturers of pharmaceuticals, laboratory supplies and/or medical devices.

\section{Financial support: None}

\section{REFERENCES}

1. Başara BB, Çağlar İS, Aygün A, Özdemir TA, eds. T.C. Sağlık Bakanlığı Sağlık İstatistikleri Y1llığı 2018. Türkiye Cumhuriyeti Sağlık Bakanlığı Sağlık Bilgi Sistemleri Genel Müdürlüğü; 2019:207,211.

2. Koduru P, Irani M, Quigley EMM. Definition, Pathogenesis, and Management of That Cursed Dyspepsia. Clin Gastroenterol Hepatol. Apr 2018;16(4):467-479. doi:10.1016/j.cgh.2017.09.002

3. de Brito BB, da Silva FAF, Soares AS, et al. Pathogenesis and clinical management of Helicobacter pylori gastric infection. World journal of gastroenterology. 2019;25(37):5578-5589. doi:10.3748/wjg.v25.i37.5578

4. Fischbach W, Malfertheiner P. Helicobacter Pylori Infection. Dtsch Arztebl Int. Jun 22 2018;115(25):429-436. doi:10.3238/arztebl.2018.0429

5. Du LJ, Chen BR, Kim JJ, Kim S, Shen JH, Dai N. Helicobacter pylori eradication therapy for functional dyspepsia: Systematic review and meta-analysis. World $\mathrm{J}$ Gastroenterol. Mar 28 2016;22(12):3486-95. doi:10.3748/wjg.v22.i12.3486

6. Liou J-M, Malfertheiner P, Lee Y-C, et al. Screening and eradication of \&lt;em\&gt;Helicobacter pylori\&lt;/em\&gt; for gastric cancer prevention: the Taipei global consensus. Gut. 2020;69(12):2093. doi:10.1136/gutjnl-2020-322368

7. Wang YK, Kuo FC, Liu CJ, et al. Diagnosis of Helicobacter pylori infection: Current options and developments. World J Gastroenterol. Oct 28 2015;21(40):11221-35. doi:10.3748/wjg.v21.i40.11221

8. Pathak CM, Kaur B, Khanduja KL. 14C-urea breath test is safe for pediatric patients. Nucl Med Commun. Sep 2010;31(9):830-5. doi:10.1097/MNM.0b013e32833c3647

9. Bentur Y, Matsui D, Koren G. Safety of 14CUBT for diagnosis of Helicobacter pylori infection in pregnancy. Can Fam Physician. May 2009;55(5):479-80.

10. Bilal R, Khaar B, Qureshi TZ, et al. Accuracy of non-invasive 13C-Urea Breath Test compared to invasive tests for Helicobacter pylori detection. J Coll Physicians Surg Pak. Feb 2007;17(2):84-8.

11. Best LM, Takwoingi Y, Siddique S, et al. Non-invasive diagnostic tests for Helicobacter pylori infection. Cochrane Database Syst Rev. Mar 15 2018;3(3):Cd012080. doi:10.1002/14651858.CD012080.pub2

12. Talley NJ, Vakil N. Guidelines for the management of dyspepsia. Am J Gastroenterol. Oct 2005;100(10):2324-37. doi:10.1111/j.1572-0241.2005.00225.x

13. Yilmaz N, Koruk Özer M. The Prevalence of Helicobacter Pylori babA, homB, aspA, and sabA Genes and Its Relationship with Clinical Outcomes in Turkey. Can J Gastroenterol Hepatol. 2019;2019:1271872. doi:10.1155/2019/1271872

14. Tarhane S, Anuk T, Gülmez Sağlam A, et al. [Helicobacter pylori Positivity and Risk Analysis in Patients with Abdominal Pain Complaints]. Mikrobiyol Bul. Jul 2019;53(3):262-273. Abdominal Ağr1 Yakınmalı Hastalarda Helicobacter pylori Pozitifliği ve Risk Analizi. doi: $10.5578 / \mathrm{mb} .68267$

15. Ünlüsoy Aksu A, Yılmaz G, Eğritaş Gürkan Ö, Sarı S, Dalgıç B. The effect of Helicobacter pylori eradication on functional dyspepsia in Turkish children. Helicobacter. Aug 2018;23(4):e12497. doi:10.1111/hel.12497

16. Serin A, Tankurt E, Şarkış C, Simsek I. The prevalence of Helicobacter pylori infection in patients with gastric and duodenal ulcers - a 10-year, single-centre experience. Prz Gastroenterol. 2015;10(3):160-163. doi:10.5114/pg.2015.49685

17. Ozaydin N, Turkyilmaz SA, Cali S. Prevalence and risk factors of Helicobacter pylori in Turkey: a nationally-representative, 
cross-sectional, screening with the ${ }^{13} \mathrm{C}$-Urea breath test. BMC Public Health. 2013;13:1215-1215. doi:10.1186/14712458-13-1215

18. Ford AC, Marwaha A, Sood R, Moayyedi P. Global prevalence of, and risk factors for, uninvestigated dyspepsia: a meta-analysis. Gut. Jul 2015;64(7):1049-57. doi:10.1136/gutjnl-2014-307843

19. Ford AC, Mahadeva S, Carbone MF, Lacy BE, Talley NJ. Functional dyspepsia. Lancet. Nov 21 2020;396(10263):1689-1702. doi:10.1016/s0140-6736(20)30469-4

20. Kanser Taramaları. T.C. Sağlık Bakanlı̆̆ı, Halk Sağlığı Genel Müdürlüğü. Accessed 04.11.2020, https://hsgm.saglik.gov.tr/tr/kansertaramalari

21. Venerito $M$, Goni E, Malfertheiner $P$. Helicobacter pylori screening: options and challenges. Expert Rev Gastroenterol Hepatol. 2016;10(4):497-503. doi:10.1586/17474124.2016.1126507

22. Kowada A. Cost-effectiveness of Helicobacter pylori screening followed by eradication treatment for employees in Japan. Epidemiol Infect. Oct 2018;146(14):18341840. doi:10.1017/s095026881800208x

23. Chey WD, Leontiadis GI, Howden CW, Moss SF. ACG Clinical Guideline: Treatment of Helicobacter pylori Infection. Official journal of the American College of Gastroenterology | ACG. 2017;112(2) 